\title{
CTL Learning Model in the Millennial Era: The Use of Edmodo-Based E-Learning Model on Geography Learning in SMA and MA Assalaam
}

\author{
${ }^{1 s t}$ Erna Mardliyana Rahmawati \\ Department of Education \\ Citizenship and Environmental, \\ Faculty of Teacher Training and \\ Education, Universitas Sebelas \\ Maret, Surakarta, Indonesia, \\ 57126 \\ ernamardlivana2@gmail.com
}

\author{
${ }^{2 n d}$ Chatarina Muryani \\ Department of Education \\ Citizenship and Environmental, \\ Faculty of Teacher Training and \\ Education, Universitas Sebelas \\ Maret, Surakarta, Indonesia, \\ 57126
}

\author{
3nd Sarwono \\ Department of Education \\ Citizenship and Environmental, \\ Faculty of Teacher Training and \\ Education, Universitas Sebelas \\ Maret, Surakarta, Indonesia, \\ 57126
}

\begin{abstract}
The purpose of this research is to find out the difference of geography learning results between using Contextual Teaching and Learning (CTL) model with Edmodo-based e-learning and using lecturing method in the topic of geographical research methods in the tenthgrade Social students of SMA and MA Assalaam Sukoharjo.
\end{abstract}

The research method used was quasi-experiment. The technique of collecting data was using written tests in the form of multiple-choice questions to measure the discriminating power, the level of difficulty, and the reliability. Liliefors method was used to test the normality while Scheffe' test was used for the data analysis test. The result of this research is that learning using Contextual Teaching and learning (CTL) model with Edmodo-based e-learning is better than lecturing to teach geographical research methods to the tenthgrade Social students of SMA and MA Assalaam Sukoharjo.

Keywords- quasi experiment, CTL, Edmodo-based e-learning, learning outcomes.

\section{INTRODUCTION}

The world of education is a very important world in human life. Education is one of the determinants of the sustainability and the progress of a nation because it will produce quality human beings. Through education, young people in one country can bring changes for the better.

The quality of education can be seen in the indicator of success in learning; that is the achievement of the defined learning objectives. One way is to increase students' understanding of the taught material that can be represented with their learning outcomes. Besides, the renewal in education is the method innovation. Methods are said to be relevant if they can lead the students to achieve educational goals through learning. A variety of learning methods that can attract students' interests and motivations must be mastered by the teacher. Teachers must improve how to teach and adjust their teaching methods with the demand of situations in performing daily tasks. The selection of methods, materials, and learning strategies should be tailored to the needs of the students.

Geography learning in high schools today is still dominated by the view that knowledge as a means of facts must be memorized. Teachers are presenters; students are recipients only; and lecturing method is still the main choice as a learning strategy that causes students to become saturated, and it has an impact on the decrease of their ability to absorb the materials. Chickering and Gamson suggest that educators use active learning strategies so that students do not just listen to lessons [1].

A good teacher should be able to create an atmosphere and learning conditions that stimulate students' interests and meet their needs in developing their potential. Teachers should also have a strategy so that students can learn effectively and efficiently and meet the goals to be achieved. One of the steps to have the strategy is that the teacher must have the ability in choosing as well as using the appropriate and effective learning methods as a means of interaction between teachers and students in the learning activities. The use of appropriate methods will affect the students' awareness to learn and seek more information because it is driven by the needs and a great sense of curiosity that is expected to further optimize the potential of each student. Teachers will no longer be the learning center, but act as facilitators where students are given wide 
opportunities to be creative in understanding the materials.

Among teenagers in Indonesia, especially from junior and senior high schools, internet is not a new thing any more. In today's global era, a person needs strong controls to choose and sort out the values that are so much offered to them. Therefore, for someone resilient, it can be done with education because the best way in building a person is through education. To produce quality students in terms of learning outcomes, it is necessary to innovate the learning models used by the teachers in learning.

The learning models used in this research are Contextual Teaching and Learning (CTL) model with Edmodo-based e-learning and lecturing model. In SMA and MA Assalaam especially in the tenth-grade social students, there have never been any researches about the use of CTL with Edmodo-based e-learning compared with the model which is often used by the teachers there; that is lecturing learning model.

CTL model is a holistic learning process that aims to educate students in understanding the meaningful materials related to the real-life context, whether they are related to personal, religious, social, economic or cultural contexts and so on. Therefore, students acquire knowledge and skills that can be applied and transferred from the context of one problem to another [2] (Suhana, 2014: 67). According to Elaine (2014: 58) CTL is a system that stimulates the brain to construct patterns that embody meanings which fit perfectly with the brain that produces meanings by linking the academic content to the context of the student's daily life [3]. Susan (2003) pointed out, "Contextual teaching and Leaning (CTL) is a concept that helps teachers relate subject matter to real world situations. CTL motivates learners to take charge of their own learning and to make connections between knowledge and its applications to the various contexts of their lives: as family members, as citizens, and as workers" [4]. Based on the above description, Contextual Teaching and Learning is a concept that helps teachers connect the learning materials with the real life. CTL motivates students to master their learning and connect knowledge and its application in their lives such as family members, communities, and individuals.

Hudson \& Whisler pointed out, "Contextual teaching and learning (CTL) is defined as a way to introduce content using a variety of active-learning techniques designed to help students connect what they already know to what they are expected to learn, and to construct new knowledge from the analysis and synthesis of this learning process" [5]. Based on the above description, CTL is a way of introducing materials using active learning techniques with variations that are made to help students relate what they already know to what they expect in the lesson, and to form new knowledge from the analysis of the learning outcomes.

Edmodo, as disclosed by Casey Stroud in his White Paper (2010: 2), is a social network whose use is devoted to education. Edmodo is a social networking application that has a similar look to Facebook but creates an on-line learning environment for students to discuss the learning materials to achieve the learning goals which make Facebook different from Edmodo [6]

E-learning is a learning system that utilizes electronic media as a tool to help learning activities. Most people assume that the electronic media in question are computer and internet technology. Through computers, students can study individually either in program or not. Whereas Edmodo is just like any other learning media. It can be an on-line platform to encourage learning by teachers or a more creative way of engaging students in learning that emphasizes collaborative aspects. This is because Edmodo provides a direction and a way to build communication for student-to-student and teacher-tostudent interactions. Edmodo has a role in providing a learning environment that can make the students happy and more independent without forgetting the standards of measuring their success (Team Developer, 2013) [7].

Cauley (2013) in Monalisa \& Ardi (2013: 221) pointed out that Edmodo is an educational website used to take ideas from social networks which are filtered to be better and politer when presented in class [8].

Lecturing is a part of conventional learning methods synonymous with traditional method. According to Dimyati and Mudjiono (2009: 77) "conventional learning method is a teaching method that has been long and used by teachers, for example by lecturing method" [9]. Lecturing learning model can make the students saturated and bored because there is no variation in the learning activities.

The implementation of CTL with Edmodo-based e-learning is in accordance with the characteristics of geographical research method topic because this model enables the students to be active in learning, improves their independence, and makes them more responsible during the learning process.

Geography learning will be more interesting if there is an innovative learning model to improve students' learning outcomes. Thus, the writer tries to conduct the research with the title: "CTL Learning Model in the Millennial Era: The Use of EdmodoBased E-Learning Model on Geography Learning in SMA and MA Assalaam ". It aims to find out the significant difference of geography learning results between using CTL model with Edmodo-based elearning and using lecturing method on the topic of geographical research methods in the tenth-grade Social students of SMA and MA Assalaam Sukoharjo.

\section{METHOD}

This research applied quantitative approach. The method used in this study was quasi-experimental research by dividing the class into two groups namely 
experimental and control groups. Quasi experimental research is an experimental activity by giving pseudotreatment. The pseudo-treatment given is to provide treatment with experimental activities of CTL model with Edmodo-based e-learning. According to Budiyono (2015: 83), "the purpose of quasiexperimental research is to obtain information that is an estimate for the informants that can be obtained by experimenting the actual manipulation of all relevant variables" [15].

The type of experimental design used was the pretest-posttest design of the random-control group. The design is included in the pseudo-experimental design, an experimental design that does not allow random placement of subjects because the control or the comparison group is absent, unsatisfactory, or expensive. Thus, in this design, the researcher selected two or more groups of the existing subjects, then gave experimental treatment. Experiments were conducted in a particular class with the existing students. The researcher was unlikely to change the class in determining the subjects for the experimental groups. The researcher selected two or more groups of existing subjects then gave an experimental treatment. The sample of this research was divided into three groups, namely two experimental classes and one control class. In this study, CTL and CTL with Edmodo were applied to the experimental class while lecturing method was applied to the control class.

At the beginning of the research, the students were given pretest to find out their initial ability. Then, the students in group 1 were treated using CTL model while those in group 2 were treated using CTL with Edmodo-based e-learning. The control group was treated using lecturing method. At the end of the research, the students did the final test (post-test). The results of both tests were used as research data to be processed and compared using statistical analysis.

The subjects of this study were the tenth-grade Social students of SMA and MA Assalaam Sukoharjo in 2016/2017 academic year. The data were obtained by using test instrument.

\section{RESULTS AND DISCUSSION}

The data analysis technique used in this research is one-way analysis of variance. Thus, it requires the fulfilment of two assumptions namely the normality and the homogeneity tests of the variants.

\section{A. Normality test}

The normality test of the students' scores of geographical research method topic includes the learning outcomes from: 1) the group of students with CTL treatment; 2) the group of students with CTL with Edmodo-based e-learning treatment; 3) the group of students with lecturing treatment. Test

Table 1. The Summary of the Data Normality

\begin{tabular}{llccl}
\hline Data & \multicolumn{1}{c}{ Class } & L & Ltable & Conclusions \\
\hline $\begin{array}{l}\text { Pre- } \\
\text { Test }\end{array}$ & CTL & 0,163 & 0,184 & Normal \\
& (Edmodo) & & & \\
\cline { 2 - 5 } & Lecturing & 0,136 & 0,159 & Normal \\
\hline $\begin{array}{l}\text { Post- } \\
\text { Test }\end{array}$ & CTL & 0,178 & 0,184 & Normal \\
\cline { 2 - 5 } & (Edmodo) & & & \\
& Lecturing & 0,151 & 0,159 & Normal
\end{tabular}

The normality determination can be seen from how to compare $\mathrm{L}$ with $\mathrm{L}_{\text {table. If }} \mathrm{L}<\mathrm{L}_{\text {table }}$, the data is normally distributed. However, if $\mathrm{L}>\mathrm{L}_{\text {table, the data }}$ is not normally distributed. Based on the pre-test and post-test data (learning outcomes), each class is normally distributed. It can be seen that the whole $\mathrm{L}$ which is less than $\mathrm{L}_{\text {table. Thus, }} \mathrm{H}_{0}$ is accepted. It can be concluded that the sample consisting of CTL with Edmodo-based e-learning class and lecturing class comes from a normally distributed population.

\section{B. Homogeneity Test}

Variant homogeneity test using Bartlett test is used to show that the population of the sample in this research is homogeneous or varies the same. Below is the homogeneity test result using Bartlet. Test

Table 2. The Summary of the Data Homogeneity

\begin{tabular}{llllll}
\multicolumn{1}{c}{ Data } & \multicolumn{1}{c}{ Class } & $\begin{array}{c}\mathbf{X}^{\mathbf{2}} \\
(\mathbf{S i g})\end{array}$ & Sig & Conclusions \\
\hline Pre-Test & $\begin{array}{l}\text { CTL } \\
\text { (Edmodo), } \\
\text { Lecturing }\end{array}$ & 0,926 & $>0,05$ & $\begin{array}{l}\mathrm{H}_{0} \\
\text { accepted }\end{array}$ & is \\
& & & & \\
\hline Post-Test & $\begin{array}{l}\text { CTL } \\
\text { (Edmodo), }\end{array}$ & 0,838 & $>0,05$ & $\begin{array}{l}\mathrm{H}_{0} \\
\text { accepted }\end{array}$ & is \\
(Learning & Lecturing & & & & \\
Outcomes) & & & & & \\
\hline
\end{tabular}

The determination of data homogeneity was conducted by reading the value of $\mathrm{X}^{2}(\mathrm{sig})$. If $\mathrm{X}^{2}(\mathrm{sig})$ $<$ alpha $(0,050)$, it can be concluded that the data is homogeneous. However, if $\mathrm{X}^{2}(\mathrm{sig})>$ alpha $(0,050)$, the data is not homogeneous. Based on the homogeneity test table, it is known that the value of $\mathrm{X}^{2}$ ( $\mathrm{sig}$ ) of pre-test is 0.926 , and that of post-test is 0.838 , larger than alpha $(0.050)$. Therefore, the data are derived from a homogeneous population.

\section{Balance Test}

The balance test is conducted to find out the ability positions of the three classes, the experimental classes and the control class. Before giving treatment to the experimental class, a balance test was conducted by comparing the pretest scores of the experimental class and those of control class using Anava test.

From the result of equilibrium calculation using Anava test, it was obtained that F is 0,542 . Since F 
$0,542<\mathrm{F}_{\text {table }} 3,97$, it can be concluded that $\mathrm{H} 0$ is accepted which means that "there is no significant difference in the treatment given to the pretest result." In other words, the experimental group and the control groups have the same initial abilities.

\section{Hypothesis Testing}

After the prerequisite analysis tests (normality and homogeneity tests), it was found that the data were in normal and homogeneous distribution. Then, the hypothesis testing was conducted using Scheffe' test. The summary of post-Anava test using Scheffe' method can be seen in Table 4 below.

Table 4. The Summary of Scheffe' Test

\begin{tabular}{lllll}
\hline \multirow{2}{*}{ Model } & \multirow{2}{*}{ Model } & \multirow{2}{*}{ Sig } & \multicolumn{2}{c}{ Notes } \\
\cline { 3 - 5 } & & & Sig. & Conclusions \\
\hline CTL & Lecturing & 0,49 & $<$ & $\mathrm{H}_{0}$ is rejected \\
with & & & 0,05 & \\
Edmodo & & & & \\
\hline
\end{tabular}

The above table shows the results of Scheffe' test about the influence of the application of Geography learning model in the form of CTL model with Edmodo-based e-learning and lecturing method on the students' learning outcomes in SMA Assalaam Sukoharjo. Significant scores were obtained from Edmodo-based e-learning and the lecturing models; that is $0.049<0.05$ (alpha). It means that there is a significant difference between the implementation of CTL model with Edmodo-based e-learning and lecturing models. Viewed from the average of the implementation, CTL model with Edmodo-based elearning results in a better average of 78.28 in comparison with the lecture model with a mean of 73.39. It can be concluded that the result of Geography learning using CTL model with Edmodobased e-learning is better than that using lecturing model on the topic of geographical research methods in the tenth-grade Social students of SMA and MA Assalaam Sukoharjo.

\section{E. Discussions}

There are different levels of effectiveness of the two learning models (CTL with Edmodo-based elearning and lecturing models) on the learning outcomes of the tenth-grade Social students of SMA and MA Assalaam Sukoharjo. Each class was given treatment in accordance with the steps of those learning models which resulted in the different learning outcomes. The average learning outcomes are strongly influenced by the learning model used. The average of learning outcomes in question is the average number of scores obtained by the students. The average comparison of the students' learning outcomes can be seen in the following table:

Table. 5 The Average of the Students' Learning Outcomes

\begin{tabular}{ll}
\hline Class & Average Scores \\
\hline CTL (Edmodo) & 78,26 \\
\hline Lecturing & 73,39 \\
\hline
\end{tabular}

Based on the above table, the researcher makes comparison histogram of the average learning outcomes with each learning model in the following figure:

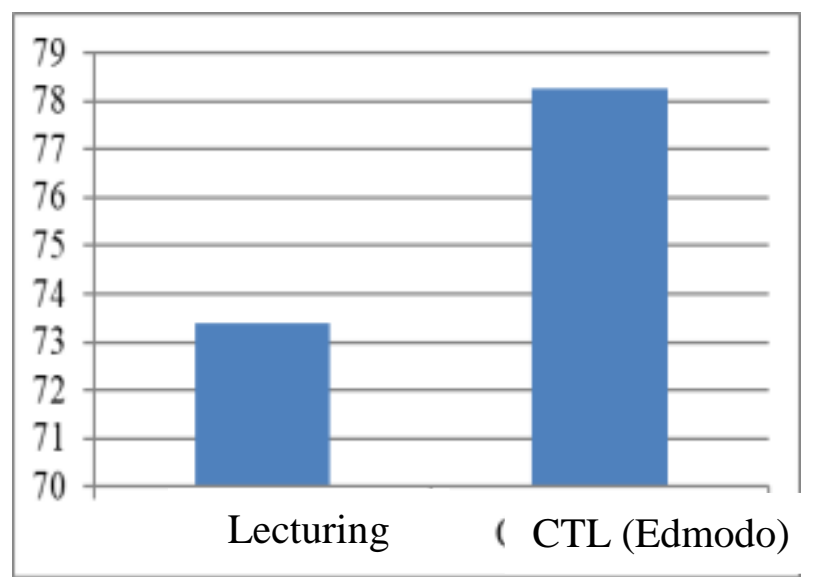

Figure 1. The Histogram of the Average of the Students' Learning Outcomes

The testing of the fourth hypothesis was conducted by comparing the mean of CTL model with Edmodo-based e-learning and lecturing model. This hypothesis testing used advanced post-Anava test using Scheffe' method with 5\% significance level. The result of the test is $0.049<0.05$ (alpha) meaning that $\mathrm{HO}$ is rejected, so there is a difference of average between CTL model with Edmodo-based elearning with the average learning outcome of 78.26 and lecturing model with average learning outcome of 73,39 . These results are in line with the fourth hypothesis stating that the result of Geography learning using CTL model with Edmodo-based elearning is better than that using lecturing model in the topic of geographical research methods in the tenth-grade Social students of SMA and MA Assalaam Sukoharjo.

\section{CONCLUSION}

Based on the results of the discussions that have been elaborated, it can be concluded that the result of Geography learning using CTL model with Edmodobased e-learning is better than that using lecturing model in the topic of geographical research methods in the tenth-grade Social students of SMA and MA Assalaam Sukoharjo. From Scheffe' test calculation with $5 \%$ significance level, the result of significance value of CTL model with Edmodo-based e-learning and lecturing model is $0,049<0,05$ (alpha) so that there is significant difference with the mean of conventional model by 73.39 and that of CTL model by 78.26. If we look at the students' conditions and their learning outcomes, appropriate learning model innovation for the students is necessary in this millennial era. The use of CTL model with Edmodobased e-learning is considered more effective than lecturing model to improve the students' learning outcomes in SMA and MA Assalaam Sukoharjo. 


\section{REFERENCES}

[1] A. W. Chickering and Z. F. Gamson. 1999. Development and Adaptations of the Seven Principles for Good Practice in Undergraduate Education. John Wiley \& Sons, Inc.

[2] Suhana, Cucu. 2014. Konsep Strategi Pembelajaran. Bandung: PT. Refika Aditama.

[3] Elaine B. Johnson. 2014.Contextual Teaching and Learning $(C T L)$. Terj.A Chaedar Alwasilah. Kaifa Learning. Bandung.

[4] Sears, Susan. 2003. Introduction to Contextual Teaching and Learning. Bloomington Indiana: The Phi Delta Kappa Educational Foundation.
[5] Hudson, C.C. \& Whisler, V.R. Contextual Teaching and Learning for Practitioners. Volume 6 (4), 54-58. ISSN:16904524.

[6] Casey, Stroud. (2010). A White Paper. EDUC 651: Connecting Technology \& Curriculum Edmodo. Winthrop University.

[7] Tim Pengembang. (2013). Buku Sumber Simulasi Digital Versi September 2013. Jakarta: Seamolec.

[8] Monalisa \& Ardi, Havid. (2013). Using "Edmodo" Educational Social Network in Teaching English for High School Students. Journal of English Language, 2, (221).

[9] Dimyati \& Mudjiono. 2009. Belajar dan Pembelajaran. Jakarta: Rhineka Cipta.

[10] Budiyono, \& Suyono (Ed.). 2015. Pengantar Metode Statistik Multivariat.Surakarta:UNS

Press. 